\title{
Bioactivities, Biomedical and Pharmaceutical Applications of Raw and Functionalized Clay Minerals: A Review
}

\author{
Adekeye $\mathrm{DK}^{1 *}$, Aremu 0I ${ }^{1}$, Fadunmade EO ${ }^{1}$, Araromi AA ${ }^{2}$, Odeniyi I ${ }^{3}$, Adedotun $\mathrm{IS}^{4}$ and Ajenikoko \\ $\mathbf{M K}^{5}$ \\ ${ }^{1}$ Department of Chemistry, Ekiti State University, Nigeria
}

${ }^{2}$ Department of Industrial Chemistry, Ekiti State University, Nigeria

${ }^{3}$ Department of Biochemistry, Ekiti State University, Nigeria

${ }^{4}$ Department of Pure and Applied Chemistry, Osun State University Osogbo, Nigeria

${ }^{5}$ Department of Anatomy, College of Medicine, Ekiti State University, Nigeria

*Corresponding author: Adekeye D Kayode, Department of Chemistry, Ekiti State University, AdoEkiti, Nigeria

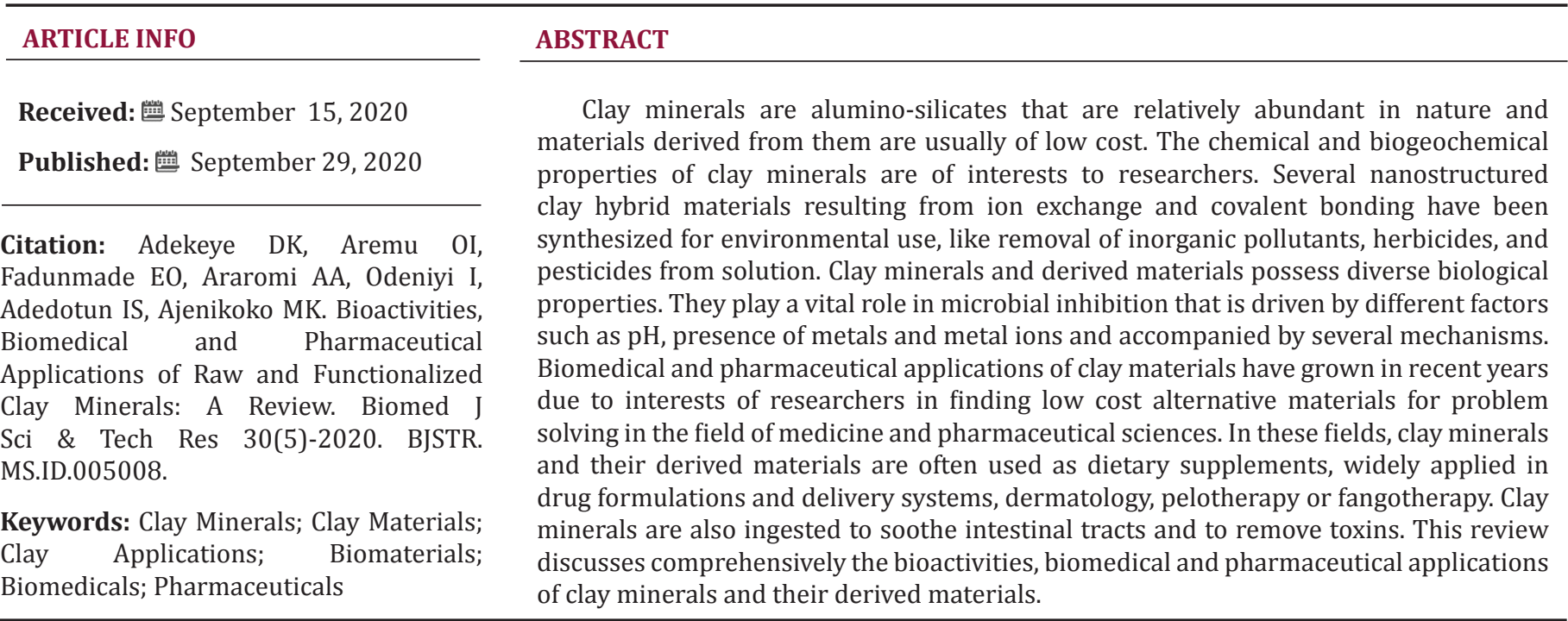

\section{Introduction}

Clay minerals are naturally abundant alumino-silicates that often occur as deposits in many parts of the world [1]. They are found in nature either as large or small deposit covering of the earth surface. They form a major part of soils in which plants grow and they are the primary raw materials in various industrial products such as adsorbents, cosmetics, pharmaceuticals, paints, veterinary medicine and biocides [2-5]. Both raw and modified clay minerals as well as materials synthesized from minerals such as kaolinite and smectite have long been used in many parts of the world to treat several human diseases and ailments including those of the digestive tract [6]. The diversity of clay mineral applications can be attributed to their chemical, geotechnical, and biological characteristics. Clay minerals consist of various elements including the transition metals as shown by Adekeye, et al. [7] (Figure 1) capable of interacting with microorganisms in soil.These elements may either be beneficial or toxic to microorganisms. Some elements may serve as sources of minerals for various biological functioning while others may be toxic to the organisms [8-10].Chemical nature 
of clay minerals greatly influences the type of microorganism that can inhabit the minerals phyllo sphere and environment.

\begin{tabular}{|l|l|c|}
\hline Atomic no. & Symbol & Conc (ppm) \\
\hline 11 & $\mathrm{Na}$ & 27510 \\
\hline 12 & $\mathrm{Mg}$ & 155101 \\
\hline 13 & $\mathrm{Al}$ & 254444 \\
\hline 14 & $\mathrm{Si}$ & 568138 \\
\hline 15 & $\mathrm{P}$ & 330 \\
\hline 17 & $\mathrm{Cl}$ & 281 \\
\hline 19 & $\mathrm{~K}$ & 2820 \\
\hline 20 & $\mathrm{Ca}$ & 2723 \\
\hline 22 & $\mathrm{Ti}$ & 2097 \\
\hline 24 & $\mathrm{Cr}$ & 261 \\
\hline 25 & $\mathrm{Mn}$ & 312 \\
\hline 26 & $\mathrm{Fe}$ & 41520 \\
\hline 29 & $\mathrm{Cu}$ & 381 \\
\hline 30 & $\mathrm{Zn}$ & 155 \\
\hline 37 & $\mathrm{Rb}$ & 35.8 \\
\hline 40 & $\mathrm{Zr}$ & 562 \\
\hline 46 & $\mathrm{Pd}$ & 20.5 \\
\hline 47 & $\mathrm{Ag}$ & 210 \\
\hline 48 & $\mathrm{Cd}$ & 90.5 \\
\hline 50 & $\mathrm{Sn}$ & 217.8 \\
\hline 82 & $\mathrm{~Pb}$ & 10.8 \\
\hline
\end{tabular}

Figure 1: Elemental composition and concentration of IreEkiti kaolinite clay soil Adekeye et al. [7].

The chemical and geobiological properties of clay minerals mediate the interactions between clays and microorganisms, giving rise to diverse mechanisms of interactions. Clay minerals are known to be biocidal in nature and are capable of inhibiting several microorganisms. Mineral $\mathrm{pH}$, presence of metals and metal ions, ion exchange and adsorption properties are common factors that promote inhibition of microorganisms [11-14]. Clay minerals have been widely applied in the field of biomedical science most especially in the areas of drug delivery system, healing of various kinds of disease and ailments, source of dietary supplements, dermatology and in drug formulations [15-17]. Clay minerals are usually employed in drug formulations in order to increase drug solubility, stabilize photo-unstable drugs under ultraviolet radiation, and retard the release rate $[18,19]$. They are thus considered biomaterials with mild biological activities.Among clay minerals, montmorillonites have been the most extensively used and investigated. This work is tailored towards reviewing the contributions of different authors in the past and present in order to explicate the microbial inhibitory activities of clay minerals and materials synthesized from them, as well as their biomedical and pharmaceutical applications. Other areas requiring further investigations on the use of clay minerals and derived materials are pinpointed in this review.

\section{Clay Minerals and Mineralogy}

Clay mineralogy has been studied for several years by many researchers which have led to advances in their applications. Recent advances in characterization and mineralogical evaluation of clay has led to the general classifications of clay minerals into three based on layer types [20]. This is also discussed in the recent work reported by Adekeye, etal. [7] on physicochemical and mineralogical evaluation of a Nigeria clay mineral. The classification of clay minerals is based upon the number and arrangement of tetrahedral and octahedral sheets in the basic structures of clay minerals. They are: 1:1 (e.g. kaolinite), 2:1 (e.g. smectite and vermiculite groups) and 2:1:1 (e.g, chlorite) clay minerals [20]. Instrumentation in characterization and mineralogical evaluation of clay has also enabled and enhanced the grouping of clay minerals into five. They are: Kaolinite, illite, chlorite, smectite and vermiculite [21]. Clay minerals are composed of hydrous aluminium layer silicates with structures similar to those of micas [22]. Unlike the micas, however, interlayers of clay minerals contain a low cationic charge that binds adjacent silicate sheets and can allow free flow of water molecules through the interlayer regions [23].

The arrangement of chemical components of clay minerals is responsible for their different chemical characteristics which include plasticity, ion exchange and adsorption [24]. The plasticity, ion exchange and adsorption characteristics of clay minerals differ from minerals to minerals [6].

\section{BIO-CLAYS}

Bio-clays are clays minerals derived from biological origin. They are usually formed as a result of metabolic actions of biological organisms, e.g, microorganisms [25]. Some researchers have been able to show the formation of clay minerals by microorganisms. Ueshima and Tazaki [26] showed the formation of nontronite by mixing a natural ferrosiliceous groundwater with polysaccharides (dextrin and pectin). Fiore, et al. [27] also observed the formation of kaolinite in a solution containing oxalate and bacteria from peatmoss soil. In an experiment by Tazaki [28], he noticed the formation of biofilms on a glass slide leaned against the internal walls of an incubation vessel containing incubated sediment derived from the Passo Real Dam located in Portalegre, Brazil. The biofilms formed on the glass slide were free of pre-existing sediment (original sediment used in the experiment) and contained only newly formed minerals. The incubated sediment consisted mainly of kaolinite, cristobalite, quartz and feldspar in contrast to the observed newly formed mineral which is composed of spheres of a Si-Fe-rich mineral, with little Al. The newly formed mineral was later characterized to be halloysite formed and developed on the bacterial cell walls, to mature there and then detach [28]. Sometimes, formation of a clay mineral by microorganism may involve biotransformation of one 
clay mineral to the other which might be as a result of microbial weathering

Microbial weathering of clay minerals is the physical erosion of the mineral grainsby microbial growth and movements. Microbial weathering fosters process of clay minerals weathering by exposing fresh surfaces to chemical attack $[29,30]$. The evidence of biotransformation of clay minerals is seen in the study reported by Kim, et al. [31] who demonstrated a significant role of microbes in promoting the smectite-to-illite reaction at room temperature and one atmosphere within two weeks of experiment. Zhang, et al. [3] also reported that smectite-to-illite reaction can be catalyzed by thermophilic bacteria at diagenetically relevant temperatures. Up till date, there has been limited information on the bioactivity of microbial synthesized clay minerals and this could be an area for further research in bioapplication of clay minerals.

\section{Bioactivities Raw and Functionalized Clay Minerals}

\section{Inhibitory Activities of Clay Minerals and Derived Materials on Microorganisms}

The activities of clay minerals on microorganisms have been much defined by their inhibitory actions. Most investigations on the activities of clay minerals on microorganisms have been tailored towards their antimicrobial effects caused by abiotic factors. The use of naturally occurring clay minerals as antimicrobial agent has received attention in recent years most especially for treating human pathogens. For instance, Morrison, et al. [10] showed that clay derived from volcanogenic hydrothermal alteration destroys bacteria through the synergistic actions of Fe and Al. Cunningham, et al. [32] identified two different natural clay mixtures which exhibited broad-spectrum antibacterial activity against Pseudomonas aeruginosa, Escherichia coli, extended-spectrum beta-lactamase E. coli, Staphylococcus aureus, Salmonella enterica, methicillin-resistant S. aureus(MRSA) and Serovar typhimurium. The authors demonstrated that the antibacterial activity of the clay samples was due to the release of some exchangeable metal ions from the surface of the minerals. Thus, antibacterial activity of these natural clays was shown to be dependent on the abiotic, microbicidal activities of desorbed metal ions [32]. The biggest interest of researchers in exploiting the activities of clay on microorganisms lies in the antimicrobial activities of the clay minerals and derived materials since antimicrobial resistant formed by microorganisms has become a global issue and threats to humanity, plants and animals, and hence the research on the use of clay materials as alternative antimicrobial agents.

For example, Morrison, et al. [33] worked on a geochemical approach to combating antibiotic resistance microorganism by the use of medicinal clay and showed that the mechanism of inactivation of the microbes was due to the synergistic effect of the metals present in the clay. Similarly, Haydel, et al. [34] showed the Broad-spectrum in vitro antibacterial activities of a natural iron- rich clay mineral that was previously used therapeutically to treat patients infected with M. ulcerans against antibiotic susceptible and antibiotic-resistant bacterial pathogens. Londono and Williams in 2016 showed the antibacterial properties of a Colombian clay and its mode of action [35]. It has been suggested that antibacterial activities of most naturally occurring clays that are of hydrothermal origin, containing illite-smectite (expandable clay) and reduced Fe phases are antibacterial in nature [36]. Several clay minerals have been successfully modified for improved physical, chemical and geotechnical properties for several applications including architecture,agriculture, pharmaceutical, medical, and other industrial applications [37-39]. Also, several materials have been synthesized from clay for similar applications. Synthetic antimicrobial clay materials prepared by exchanging their native ions with known antibacterial ions such silver ion $\mathrm{Ag}+$ have been reported [40-42]. The principle involves gradual release of the novel bioactive exchanged ions from the synthetic clay for longterm antibacterial effectiveness.

Thus far, silver-loaded clays have been the most investigated material and pursued more aggressively than other antibacterial chemical ion options, although there have been efforts on investigating copper-loaded clay mineral substrates as effective antimicrobial agents in recent times [43]. Copper-loaded vermiculite has been reported to have good antifungal and antibacterial activity Li, et al. [9]. Also, antimicrobial activities of tetracycline (TC) and minocycline-montmorillonites have been demonstrated by [4]. The tetracycline and minocycline ligands were loaded into the natural montmorillonite clay by adsorption techniques and their results showed that the adsorption complexes of the clay mineral with TC were more potent than the raw clay at vary concentrations on the targeted microorganism E. coli(Figures 2\&3).Most research on the antimicrobial activities of clay minerals have been much centered on human pathogenic microorganisms, only a few studies have been reported on the use of clay to combat plants' diseases causing microbes.
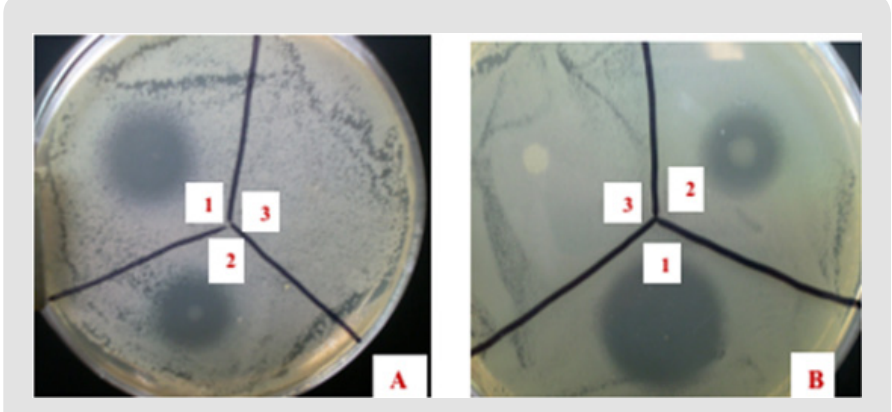

Figure 2: Inhibition zone test.

A. 1: TC solution $(1.3 \mathrm{mg} / \mathrm{mL}) ; 2$ : TC-montmorillonite (0.46 mmol/g), 3: raw montmorillonite dispersion.

B. 1 : TC solution $(1.3 \mathrm{mg} / \mathrm{mL})$; 2 : TC-mont-morillonite (0.76 mmol/g); 3: raw montmorillonite dispersion [4]. 


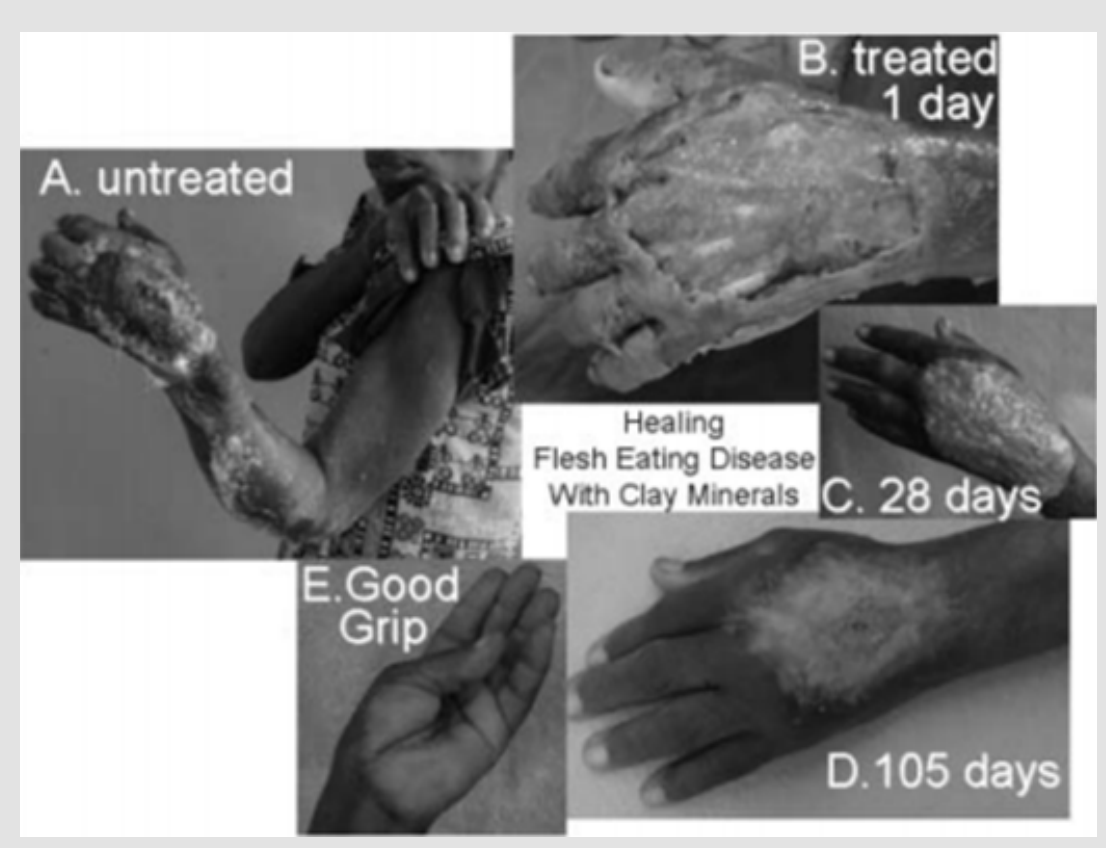

Figure 3: Buruli ulcer (a Mycobacterial infection) that

A. (A): Application of French green clay to untreated Buruli ulcer;

B. (B, C and D): Healing activity of the clay after 1 day, 28 and 105 days respectively [55].

For instance, Kaolinite clay has been formulated as a crop protectant and has been shown to have a sublethal impact on fungal pathogens [44]. Puterka, et al. [45] reported the possible application of clay minerals in management and control of pear diseases causing microorganisms. Kaolin mineral have been tried for the control of powdery mildew on field grown squash in Israel, Marco, et al. [46] and greenhouse cucumbers in Canada [47]. Elizabeth, et al. [48] also reported the potential use of kaolin clay for disease control in greenhouse cucumbers. Up till date, there is still little information on the use of natural clay and derived materials in treating and managing plants pathogenic diseases caused by microorganisms. This could be an area for further investigation.

\section{Healing and Medicinal Activities of Natural Clay Minerals and Derived Materials}

The use of natural clay minerals as bioactive agents according to Mahaney, et al. [49] was dated back to the days of Aristotle while the first recorded studies on the medicinal applications of clay minerals by the Romans were dated back to $60 \mathrm{BC}$ according to Carretero [50]. Most early research on medicinal applications of clay minerals focused on the use of clay to treat the skin infections and disorders [51,52]. Smectite clay minerals have the potentials to adsorb dissolved and suspended organic and inorganic substances as well as, bacteria and viruses, while kaolinite and palygorskite are primarily used to soothe the digestive tract $[50,53,54]$. Several human diseases have been successfully treated by clay minerals; for instance, Line Brunet de Courssou, a French humanitarian working in Cote d'Ivoire (Ivory Coast) a country located in West Africa, presented to the World Health Organization the results of her research on treatment of Buruli ulcer (known to be a flesh eating disease that destroys fatty tissues under the skin and caused by Mycobacterium ulcerans) [55]. The physical adsorption of water and organic matter has been suggested to be the most common attribute of the healing properties of clays [56]. It was reported that the Uitoto people of the Colombian Amazon recognized and employed the curative properties of a naturally occurring clay majorly composed of kaolinite and smectite in the Colombian Amazon region.

They ingest the clay to alleviate diarrhea and digestive discomfort [57]. The clay was shown to be antibacterial using standard antimicrobial susceptibility testing [57]. Conversely, living things including microorganisms also require metal nutrients for proper functioning of the cells which are either derived from minerals, colloids, solutions or decaying organic matter. Clay minerals contain many of these bioactive metals in different concentrations [5]. Dissolution of the metals in runoff or underground water is a possible way by which human can absorb these essential minerals water. Also, microorganisms in the soil may benefit from these minerals either by dissolution, ion exchange mechanism or absorption for their biological functioning. The order of decreasing required amounts of metal nutrient requirements that can typically be provided by clay minerals have been shown to be $\mathrm{K}>\mathrm{Na}>\mathrm{Mg}>\mathrm{Ca}>\mathrm{Fe}>>\mathrm{Mn}, \mathrm{Co}, \mathrm{Zn}, \mathrm{Cu}, \mathrm{Si}, \mathrm{Ni}$ and $\mathrm{Mo}[8,58]$. 
The incorporation of clay minerals into drugs has received a great deal of attention for biomedical applications. Various polar and nonpolar drug molecules can be combined with clay minerals by different techniques including adsorption and intercalation to form clay-drug hybrid materials.

Several attempts have been made to design and develop orally administered clay-drug hybrids for chemotherapy with lower adverse side effect. For examples, 5-fluorouracil (5-FU) was intercalated into montmorilonite (Mnt) in order to reduce the perceived toxicity of the drug and to achieve controlled release for colorectal cancer therapy $[59,60]$. The resultant 5-FU/Mnt hybrid was expected to achieve in situ release for colorectal cancer therapy. Organically modified montmorillonite has also been reported to have found application in bone-related biomedical in form of bonecement [61].

\section{Biomedical and Pharmaceutical Applications of Clay Minerals and Derived Materials}

\section{Clay Minerals as Dietary Supplements}

The ingestion of natural clay minerals usually in form of suspension is commonly used as a source of dietary mineral supplement, as a detoxifying agent, and as an allopathic treatment of acute and chronic diarrhea [62]. The intentional consumption of soil materials, such as clays, by animals and humans is known as geophagy [63]. Geophagy is a poorly understood practice that is largely attributed to cultural practices, religious beliefs, medicinal benefits, psychological disorders, and dietary/nutritional needs $[64,65]$. Historically, it is believed to be practiced to remedy a physiological response to mineral nutrient deficiencies, such as calcium, magnesium, iron or zinc, to satisfy dietary nutritional requirement; to ease obsessive-compulsive disorder and psychosocial problems including anxiety $[66,67]$. However, studies and medical reports have shown that ingesting large amounts of clay (>200 grams per day) with high cation-exchange capacity can impede absorption of iron, zinc, and potassium, leading to iron, zinc, or potassium deficiencies [68-73]. Moderate ingestion of clays like kaolin containing minerals like iron, copper, zinc, calcium, and manganese and lacking high cation-exchange capacities could serve as nutritional supplements. In Nigeria, it has been reported that Women of the Tiv tribe eat sub-surface clay, particular during and shortly after pregnancy [74].

Mineralogical investigation of the clay found in this region showed a higher concentration of calcium and magnesium relative to the surface soil [75]. The Tiv people are known as one of the only tribes that do not drink animal milk because milk-producing animals are susceptible to parasitic infections that are endemic in the area. The dietary intake of calcium and magnesium through clay minerals is thought to be minimal. It was reported that in 2014, the Department of Soil Science at Bihar Agricultural University, India discovered that Karu Paswan who is more than 100 years of age at a village of Babupur (Bakharpur) in Pirpainti Block of Bhagapur District in Bihar (India), has been daily eating a type specific soil of Ganga flood plain for over last 60 years as daily dietary supplements and for its therapeutic reasons [16].

\section{Clay Minerals as Detoxifying Agents}

It has been shown by several researchers that, in the acidic environment of the stomach, clay minerals could adsorb or bind directly with positively and negatively charged toxins, thereby serving as detoxifying agents [76-79]. There are drug formulations that have been reportedly sold over-the-counter that originally contained clay minerals such as kaolinite and attapulgite, for the treatment of diarrhea and intestinal illnesses and soothe gastrointestinal ailments Vermeer and Ferrell [74] but some of these drugs were reformulated and now contain bismuth subsalicylate instead of kaolinite or attapulgite[62]. Biological applications of natural clay minerals as detoxifying agents may be attributed to their ability to adsorb lipids, proteins, bacteria, and viruses $[15,74,80,81]$. Also, clays can externally adsorb toxins from skin and are used to catalyze rheumatism treatment $[62,82]$. Furthermore, Mishra, et al. [83] explained that clay crystals are negatively charged and can attract bacteria and toxins in human body that are positively charged and thus become electrically satisfied holding the materials until the human body is able to excrete them. The properties of montmorillonite clay, such as its ability to absorb and remove various types of toxins and the ability to cross the digestive tracts have been reported $[84,85]$.

\section{Clays in Drug Delivery and Pharmaceutical Formulations}

Choy et al. [17] identified some advantages of clay minerals in drug delivery system (DDS) that include reduced side effects, fast transportation mechanisms and low toxicity. New organic and inorganic clay hybrid materials have been developed and widely investigated for their application in drug delivery system (DDS) and various pharmaceutical formulations in the last two decades because of their fast, safe, and efficient transporting mechanisms[86-93].Multifunctional poly (d, l-lactide-coglycolide)/montmorillonite(plga/mmt) nanoparticles (PLGA/ Mnt NPs) decorated by trastuzumab (human epidermal growth factor receptor-2 (HER2) antibody), a chemotherapeutic drug for treating breast cancer was developed by Sun, et al. [94]. The drug was shown to have reduced the adverse side effects of the model anticancer drug employed (paclitaxel (Pac)) and possessed synergistic therapeutic effects by achieving targeted delivery. An approach to improve drug release was made by using kaolinite pellets through extrusion-spherization and subsequently the drug molecules were loaded by a vacuum impregnation technique [95]. The drug molecules loaded in the pellets were reported to exhibit a prolonged-release profile following an 'initial burst' release as a result of entrapment within the porous structure of the pellets [95]. Kevadiya and Bajaj [96] showed a possible mechanism (Figure 4) 
by which monmorillonite could be released and absorbed in the body.

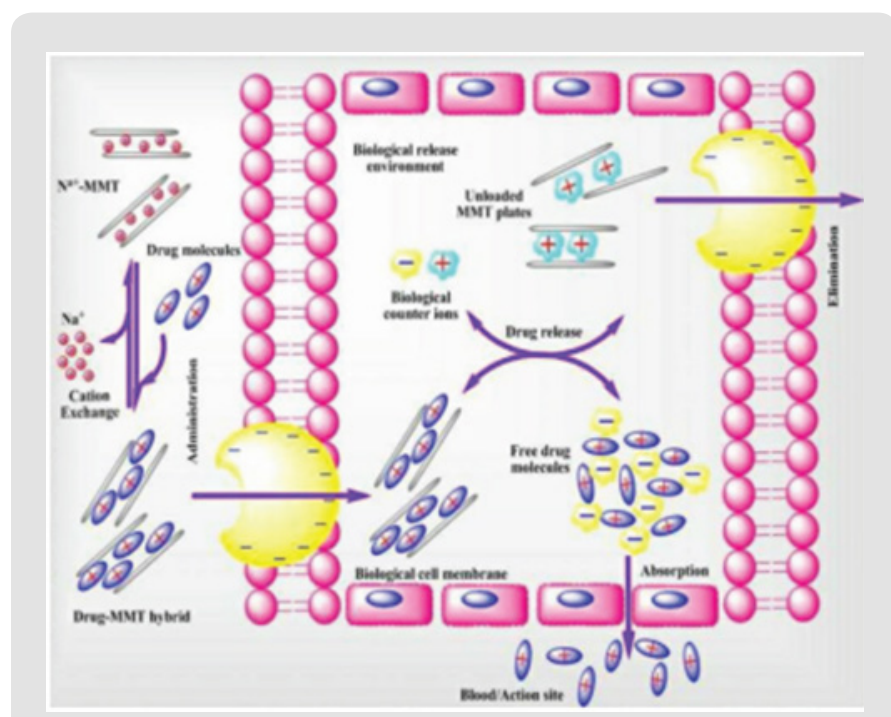

Figure 4: Mechanism of release of MMT and absorption in the body [96].

In another experiment by Bonina, et al. [97], salicylic acid, a transdermal drug was incorporated into bentonite for controlled drug release via transdermal route.In drug formulation, clay minerals have been utilized as additives in order to improve the solubility of poorly soluble drugs Dornelas, et al. [98,92];photo and thermal stability as well as dispersion of other bioactive molecules [99-102]. Several studies have also shown the efficacy of clay mineral in providing mucoadhesive properties for increasing retention time in mammalian gastrointestinal (GI) tract and the preocular surface [103-105]. The use of sodium (Na) rich smectite clay as effective laxative, stimulating defecation through osmosis, and Cacium (Ca) rich smectite clay as anti-diarrhea agents, via oral administration have been reported in the past century $[106,107]$. Clay minerals are also used as gelling, emulsifying, and thickening agents in pharmaceutical formulations for various oral medications because of their high water and oil adsorption as well as their ability to modulate viscosity efficiently $[108,109]$. Organoleptic qualities such as unpleasant taste, colour and smells of pharmacological formulations can be corrected and improved by the use of clay mineral [110].

For instance, the intercalation of Aripiprazole (APZ) into montmorillonite clay was carried out in order to improve the tasteblocking efficiency and also to control the release kinetics [111]. The aim of the study was achieved by cation exchange reaction that occurred between the APZ and the montmorillonite clay to yield a clay-drug nanohybrid, [111]. In the year 2012, Lee et al. also reported the improved taste of sildenafil by masking the drug with clay nanoparticles to form a nanohybrid [110].

\section{Dermatological Application}

Clay minerals naturally occur and are found in abundance in different parts of the world. Man has used since antiquity, in different ways, clays and mud or for therapeutic purposes, either by ingesting them or applying it topically in the form of cataplasms, patches, or mud-baths [112,113]. Clay minerals are widely applied in mud therapy, pelotherapy or fangotherapy [114116]. In dermatology, clay minerals are useful for the production of ointment to treat oily skin and acne as well being used to release drugs at a controlled kinetics to systemic circulation through passive diffusion across the skin [17]. Clay minerals have also been employed as pharmaceutical ingredients for transdermal drug delivery systems (TDDS) [87]. Studies have shown that the main factors relating to skin permeability of drug molecules which include diffusion coefficient, concentration gradient and distribution coefficient can be controlled by incorporating clay minerals to drug formulation. Indomethacin, when coupled with Montmorillonite was reported to possess better skin permeability efficiency as evaluated by the in vitro Franz cell diffusion method [18]. Indomethacin-montmorillonite (IDM-Mnt) complex formed in the process was found to be almost three times more soluble than the raw indomethacin as a result of hydrogen bonding formed between the drug and clay mineral (Ito et al 2001). Applications of clay in cosmetics have been reported Carretero and Pozo.

\section{Conclusion}

Clay minerals in their raw and modified form have been shown by several researchers to possess biologically active properties. The Bioactivities of clay materials are dependent on their chemical nature and biogeochemical properties Susceptibility of a microorganism is influenced by the chemical composition of materials in used. Clay minerals possess healing and medicinal properties; they are used as dietary supplements, widely applied in drug formulations and delivery system, in cosmetics, dermatology and mud therapy. There has been limited information on the bioactivity of microbially synthesized clay minerals and this could be an area for further research in bio application of clay minerals. Up till date, there is still little known information on the use of natural clay and derived materials in treating and managing plants diseases caused by pathogenic microorganisms. This also could be an area for further research in the use of clay materials for problem solving in agriculture with respect to plants' pathogenic microorganisms.

\section{References}

1. Awokunmi EE, Asaolu SS (2017) Physicochemical and performance evaluation of natural and modified Ire-Ekiti clay: Emerging substrate in the de-fluoridation of drinking water. Journal of physical and chemical sciences 5(4): 2348-3270.

2. Carretero MI (2002) Clay minerals and their beneficial effects upon human health. A review. Applied Clay Science 21(3-4): 155-163. 
3. Zhang G, Kim JW, Dong H, Sommer AJ (2007) Microbial effects in promoting the smectite to illite reaction: Role of organic matter intercalated in the interlayer. A Mineral 92: 1401-1410.

4. Parolo ME, Fernández LG, Zajonkovsky I, Sánchez MP, Baschini M (2011) Antibacterial activity of materials synthesized from clay minerals Science against microbial pathogens: Communicating current research and technological advances. pp. 144-151.

5. Adekeye D, Popoola O, Asaolu S, Ibigbami O, Olatoye A, et al. (2019a) Physicochemical Characterization and Mineralogical Evaluation of IreEkiti Clay deposit in Southwestern Nigeria. International Journal of Engineering Applied Sciences and Technology 4(8): 94-99.

6. Ferrell RE (2008) Medicinal clay and spiritual healing clays. clay miner 56: 751-760.

7. Adekeye DK, Asaolu SS, Adefemi SO, Ibigbami OA, Adebawore AA, et al. (2019b) Clay Soil Modification Techniques for the Adsorption of heavy Metals in aqueous Medium: A Review. International Journal of Advanced Research in Chemical Sciences 6(6): 14-31.

8. Prescott L, Harley J, Klein D (1999) Microbiology (4 $4^{\text {th }}$ Edn.,). McGraw Hill, New York.

9. Li B (2002) Antibacterial vermiculite nano-material". Journal of the Minerals Metals and Materials Society 1: 61-68.

10. Morrison KD, Underwood JC, Metge DW, Eberl DD, Williams LB (2014) Mineralogical variables that control the antibacterial effectiveness of a natural clay deposit. Environ Geochem Health 36(4): 613-631.

11. Sparling DW, Lowe P (1996) Environmental hazards of aluminum to plants, invertebrates, fish, and wildlife. In: Ware GW, Gunther FA (Eds.). Reviews of Enviromental Contamination and Toxicology. Springer: New York. pp 1-127.

12. Moberly JG, Staven A, Sani RK, Peyton BM (2010) Influence of pH and inorganic phosphate on toxicity of zinc to Arthrobacter sp. isolated from heavy-metal-contaminated sediments. Environmental Science \& Technology 44: 7302-7308.

13. Santo C, Lam E, Elowsky C, Quaranta D, Domaille D, et al. (2011) Bacterial killing by dry metallic copper surfaces. Applied and Environmental Microbiology 77: 794-802.

14. Wu H, Chen W, Rong X, Huang Q (2014) Adhesion of Pseudomonas putida onto kaolinite at different growth phases. Chem Geol 390: 1-8.

15. Schiffenbauer M, Stotzky G (1982) Adsorption of coliphages T1 and T7 to clay minerals. Applied and Environmental Microbiology 43(3): 590596.

16. Mishra BB, Richa R (2015) Soil Science Vs Science for Medicine. EC Agriculture 2(5): 454-461.

17. Choy J, Kim MH, Choi G, Elzatahry A, Vinu A, et al. (2016) Review of Clay-Drug Hybrid Materials for Biomedical Applications: Administration Routes. Clays and Clay Minerals 64(2): 115-130.

18. Ito T, Sugafuji T, Maruyama M, Ohwa Y, Takahashi T (2001) Skin penetration by indomethacin is enhanced by use of an indomethacin/ smectite complex. Journal of Supramolecular Chemistry 1: 217-219.

19. Shaikh S, Birdi A, Qutubuddin S, Lakatosh E, Baskaran H (2007) Controlled release in transdermal pressure sensitive adhesives using organ silicate nanocomposites. Annals of Biomedical Engineering 35: 2130-2137.

20. Brady N (1990) Soil Colloids: Their Nature and Practical Significance. The Nature and Properties of Soils, $\left(10^{\text {th }}\right.$ Edn.,). Macmillan Publishing Co. New York. 177-212.

21. Mohammad KU (2017) A review on the adsorption of heavy metals by clay minerals, with special focus on the past decade. Chemical Engineering Journal 308: 438-462.

22. Grim RE (1962) Applied Clay Mineralogy, McGraw Hill Press.
23. Fu F, Wang Q (2011) Removal of heavy metal ions from wastewaters: A review. Journal of Environmental Management 92(3): 407-418.

24. Hongo T, Yoshino S, Yamazaki A, Satokawa S (2012) Mechano-chemical treatment of vermiculite in vibration milling and its effect on lead (II) adsorption ability. Applied Clay Science 70: 74-78.

25. Javier C (2017) Clay minerals interaction with microorganisms: A review. Clay Minerals 52: 235-261.

26. Ueshima M, Tazaki K (2001) Possible role of microbial polysaccharides in nontronite formation. Clays and Clay Minerals 49: 292-299.

27. Fiore S, Dumontet S, Huertas FJ, Pasquale V (2011) Bacteria-induced crystallization of kaolinite. Applied Clay Science 53(4): 566-571.

28. Tazaki K (2005) Microbial formation of a halloysite-like mineral. Clays and Clay Minerals 53: 224-233.

29. Gazzè SA, Saccone L, Ragnarsdottir KV, Smits MM, Duran AL, et al. (2012) Nanoscale channels on ectomycorrhizalcolonized chlorite: Evidence for plant-driven fungal dissolution. Journal of Geophysical Research 117: G00N09.

30. Li Z, Liu L, Chen J, Teng HH (2016) Cellular dissolution at hypha- and spore-mineral interfaces revealing unrecognized mechanisms and scales of fungal weathering. Geology 44(4): 319-322.

31. Kim JW, Dong H, Seabaugh J, Newell SW, Eberl DD (2004) Role of microbes in the smectite-to-illite reaction. Science 303: 830-832.

32. Cunningham TB, Koehl JL, Summers JS, Haydel SEI (2010) Dependent metal ion toxicity influences of the antibacterial activity of two naturals mineral mixtures. PLoS One 5(3): e9456.

33. Morrison KD, Misra R, Williams LB (2016) Unearthing the antibacterial mechanism of medicinal clay: A geochemical approach to combating antibiotic resistance. Sci Rep 6: 19043.

34. Haydel SE, Remenih CM, Williams LB (2008) Broad-spectrum in vitro antibacterial activities of clay minerals against antibiotic susceptible and antibiotic-resistant bacterial pathogens. J Antimicrob Chemother 61(2): 353-361.

35. Londoño SC, Williams LB (2016) Unraveling the antibacterial mode of action of a clay from the Colombian Amazon. Environ Geochem Health 38(2): 363-379.

36. Jaiswal A, Banerjee S, Mani R, Chattopadhyaya MC (2013) "Synthesis, characterization and application of goethite mineral as an adsorbent". Journal of Environmental Chemical Engineering 1(3): 281-289.

37. Todar K (2016) Online Textbook of Bacteriology.

38. Ambrogi V, Nocchetti M, Latterini L (2014) Promethazine montmorillonite inclusion complex to enhance drug photostability. Langmuir 30: 14612-14620.

39. Ji M, Su X, Zhao Y, Qi W, Wang Y, et al. (2015) Effective adsorption of $\mathrm{Cr}(\mathrm{VI})$ on mesoporous Fe-functionalized Akadama clay: Optimization, selectivity, and mechanism. Applied Surface Science 344: 128-136.

40. Ohashi F (1993) Antimicrobial and antifungal agents derived from clay minerals. J Antibact Antifung Agents Japan 21(11): 591-595.

41. Ohashi F, Oya A, Duclaux L, Beguin F (1998) Structural model calculation of antimicrobial and antifungal agents derived from clay minerals. Applied clay science 12: 435-445.

42. Marini M, Bondi M, Iseppi R, Toselli M, Pilati F (2007) Preparation, and antibacterial activity of hybrid materials containing quaternary ammonium salts via sol-gel process. European Polymer Journal 43: 3621-3628.

43. Gant VA, Wren MWD, Rollins MSM, Jeanes A, Hickok SS, et al. (2007) Three novel highly charged copper-based biocides: Safety and efficacy against healthcare-associated organisms. Journal of Antimicrobial Chemotherapy 60: 294-299. 
44. Glenn DM, Puterka GJ, Vanderzwet T, Byers RE, Feldhake C (1999) Hydrophobic particle films: A new paradigm for suppression of arthropod pests and plant diseases. J Econ Entomol 92: 759-771.

45. Puterka GJ, Glenn DM, Sekutowski DG, Unruh TR, Jones SK (2000) Progress toward liquid formulations of particle films for insect and disease control in pear. Environ Entomol 29: 329-339.

46. Marco S, Ziv O, Cohen R (1994) Suppression of powdery mildew in squash by applications of whitewash, clay and antitranspirant materials. Phytoparasitica 22: 19-29.

47. Ehret DL, Koch C, Menzies J, Sholberg P, Garland T (2001) Foliar sprays of clay reduce the severity of powdery mildew on long English cucumber and wine grapes. Hort Science 36: 934-936.

48. Elizabeth ML, Erin NR (2002) Use of Kaolin Clay for Disease Control in Greenhouse Cucumbers. Proc Fla State Hort Soc 115: 180-182.

49. Mahaney WC, Milner MW, Mulyono H, Hancock RGV, Aufreiter S, et al. (2000) Mineral and chemical analyses of soils eaten by humans in Indonesia. International Journal of Environmental Health Research 10 93-109.

50. Williams LB, Holland M, Eberl DD, Brunet L (2004) Killer Clays! Natura antibacterial clay minerals. Mineralogical Society Bulletin. p. 1-8.

51. Williams LB, Haydel SE, Giese RF, Eberl DD (2008) Chemical, and mineralogical characteristics of french green clays used for healing. Clays Clay Miner 56(4): 437-452.

52. Gładysz Płaska A, Majdan M, Pikus S, Sternik D (2012) Simultaneous adsorption of chromium (VI) and phenol on natural red clay modified by HDTMA. Chem Eng J 179: 140-150.

53. Akpomie KG, Odewole OA, Ibeji CU, Okagu OD, Agboola II (2017) Enhanced Sorption of Trivalent Chromium unto Novel Cassava Peel Modified Kaolinite Clay. Der Pharma Chemica 9(5): 48-55.

54. Brunet de Courssou L (2002) $5^{\text {th }}$ WHO Advisory Group Meeting on Buruli Ulcer, Study Group Report on Buruli Ulcer Treatment with Clay. Geneva, Switzerland.

55. Williams L, Metge DW, Eberl DD, Harvey RW, Turner AG, et al. (2011) What makes a natural clay antibacterial? Environ Sci Technol 45: 37683773.

56. Londono SC, Hartnett HE, Williams LB (2017) Antibacterial Activity of Aluminum in Clay from the Colombian Amazon. Environ Sci Technol 51: 2401-2408.

57. Lin FH, Lee YH, Jian CH, Wong JM, Shieh MJ, et al. (2002) A study of purified montmorillonite intercalated with 5-fluorouracil as drug carrier. Biomaterials 23: 1981-1987.

58. Kevadiya BD, Patel TA, Jhala DD, Thumbar RP, Harshad Brahmbhatt, et al. (2012) Layered inorganic nanocomposites: A promising carrier for 5-fluorouracil (5-mFU). European Journal of Pharmaceutics and Biopharmaceutics 81(1): 91-101.

59. Wang JH, Young TH, Lin DJ, Sun MK, Huag HS, et al. (2006) Preparation of clay/PMMA nanocomposites with intercalated or exfoliated structure for bone cement synthesis. Macromolecular Materials and Engineering 291: 661-669.

60. Williams LB, Haydel SE (2010) Evaluation of the medicinal use of clay minerals as antibacterial agents. Int Geol Rev 52(7/8): 745-770.

61. Wilson MJ (2003) Clay mineralogical and related characteristics of geophagic materials. Journal of Chemical Ecology 29(7): 1525-1547.

62. Abrahams PW, Parsons JA (1996) Geophagy in the tropics: a literature review. The Geographical Journal 162: 63-72.

63. Aufreiter S, Hancock RGV, Mahaney WC, Stambolic Robb A, Sanmugadas K (1997) Geochemistry and mineraology of soils eaten by humans. International Journal of Food Sciences and Nutrition 48(5): 293-305.

64. Sayetta RB (1986) Pica: an overview. American Family Physician 33(5): 181-185.
65. Lacey EP (1990) Broadening the perspective of pica: Literature review. Public Health Reports 105(1): 29-35.

66. Cavdar AO, Arcasoy A, Cin S (1977) Pica with zinc deficiency. Lancet 1 : 761.

67. Cavdar AO, Arcasoy A, Cin S (1977) Zinc deficiency in Turkey. American Journal of Clinical Nutrition 30(6): 833-834.

68. Arcasoy A, Cavdar AO, Babacan E (1978) Decreased iron and zinc absorption in Turkish children with iron deficiency and geophagia. Acta Haematologica 60: 76-84.

69. Gonzalez JJ, Owens W, Ungaro PC, Werk EE, Wentz PW (1982) Clay ingestion: a rare cause of hypokalemia. Annals of Internal Medicine 97(1): 65-66.

70. Severance J, Harry W, Holt T, Patrone NA, Chapman L (1988) Profound muscle weakness and hypokalemia due to clay ingestion. South Medical Journal 81(2): 272-274.

71. Ukaonu C, Hill DA, Christensen F (2003) Hypokalemic myopathy in pregnancy caused by clay ingestion. Obstetrics \& Gynecology 102(5 Pt 2): 1169-1171.

72. Vermeer DE, Ferrell RE (1985) Nigerian geographical clay: a traditional antidiarrheal pharmaceutical. Science 227(4687): 634-636.

73. Vermeer DE (1966) Geography among the TIV of Nigeria. Annals of the Association of American Geographers 56(2): 197-204.

74. Johns T, Duquette M (1991) Traditional detoxification of acorn bread with clay. Ecology of Food and Nutrition 25(3): 221-228.

75. Phillips TD, Sarr AB, Grant PG (1995) Selective chemisorption and detoxification of aflatoxins by phyllosilicate clay. Natural Toxins 3(4): 204-213.

76. Mahaney WC, Hancock RGV, Aufreiter S, Huffman MA (1996) Geochemistry and clay mineralogy of termite mound soil and the role of geography in chimpanzees of the Mahale Mountains, Tanzania. Primates 37(2): 121-134.

77. Phillips TD (1999) Dietary clay in the chemoprevention of aflatoxininduced disease. Toxicological Sciences 52(Suppl 1): 118-126.

78. Adamis Z, Timar M (1980) Investigations of the effects of quartz, aluminum silicates and colliery dusts on peritoneal macrophages in vitro. In: Brown RC, Gormley IP, Chamberlain M, Davies R (Eds.).). The in vitro effects of mineral dusts. London: Academic Press. p. 13-18.

79. Lipson SM, Stotzky G (1983) Adsorption of reovirus to clay minerals: Effects of cation-exchange capacity,cation saturation, and surface area. Applied and Environmental Microbiology 46(3): 673-682.

80. Gomes CSF, Silva JBP (2007) Minerals and clay minerals in medical geology. Applied Clay Science 36: 4-21

81. Mishra, BB, Kibret K, Feyissa S, Roy R (2017) Clinical Relevance of Type Specific Clays. Biomed J Sci \& Tech Res 1(5): 1429-1432.

82. Forni F, Iannuccelli V, Coppi G, Bernabei MT (1989) Effect of montmorillonite on drug release from polymeric matrices. Archiv der Pharmazie (Weinheim) 322(11): 789-793.

83. Viseras C, Aguzzi C, Cerezo P, Lopez Galindo A (2007) Uses of clay minerals in semisolid health care and therapeutic products. Applied Clay Science 36(1-3): 37-50.

84. Choy JH, Kwak SY, Park JS, Jeong YJ, Portier J (1999) Intercalative nanohybrids of nucleoside monophosphates and DNA in layered metal hydroxide. Journal of the American Chemical Society 121(6): 1399-1400.

85. Kim MH, Park, DH, Yang JH, Choy YB, Choy JH (2013) Drug-inorganicpolymer nanohybrid for transdermal delivery. International Journal of Pharmaceutics 444(1-2): 120-127.

86. Oh JM, Kwak SY, Choy JH (2006) Intracrystalline structure of DNA molecules stabilized in the layered double hydroxide. Journal of Physics and Chemistry of Solids 67(5-6): 1028-1031. 
87. Kim J, Kim HS, Lee N, Kim T, Kim H, et al. (2008) Multifunctional uniform nanoparticles composed of a magnetite nanocrystal core and a mesoporous silica shell for magnetic resonance and fluorescence imaging and for drug delivery. Angewandte Chemie International Edition 47(44): 8438-8441.

88. Suresh R, Borkar S, Sawant V, Shende V, Dimble S (2010) Nanoclay drug delivery system. International Journal of Pharmaceutical Sciences and Nanotechnology 3(2): 901-905.

89. Viseras C, Cerezo P, Sanchez R, Salcedo I, Aguzzi C (2010) Current challenges in clay minerals for drug delivery. Applied Clay Science 48(3): 291-295.

90. Lim EK, Huh YM, Yang J, Lee K, Suh JS, et al. (2011) pH triggered drug releasing magnetic nanoparticles for cancer therapy guided by molecular imaging by MRI. Advanced Materials 23(21): 2436-2442.

91. Wang W, Yu JC, Xia D, Wong PK, Li Y (2013) Graphene and g-C3N4 nanosheetscowrapped elemental $\alpha$-sulfur as a novel metal-free hetero junction photocatalyst for bacterial inactivation under visible-light. Environ. Sci. Technol 47(15): 8724-8732.

92. Sun B, Ranganathan B, Feng SS (2008) Multifunctional poly (d, l-lactideco-glycolide) /montmorillonite (plga/mmt) nanoparticles decorated by trastuzumab for targeted chemotherapy of breast cancer. Biomaterials 29(4): 475-486.

93. Byrne R, Deasy P (2005) Use of porous aluminosilicate pellets for drug delivery. Journal of Microencapsulation 22(4): 423-437.

94. Kevadiya BD, Bajaj HC (2013) The layered silicate, montmorillonite (MMT) as a drug delivery carrier. Key Engineering Materials 571: 111132.

95. Bonina F, Giannossi M, Medici L, Puglia C, Summa V, et al. (2007) Adsorption of salicylic acid on bentonite and kaolin and release experiments. Applied Clay Science 36(1-3): 77-85

96. Dornelas CB, Silva AM, Dantas CB, Rodrigues CR, Coutinho SS, et al (2011) Preparation and evaluation of a new nano pharmaceutical excipients and drug delivery system based in polyvinylpyrrolidone and silicates. Journal of Pharmacy \& Pharmaceutical Sciences 14(1): 17-35.

97. El Nahhal Y, Nir S, Margulies L, Rubin B (1999) Reduction of photodegradation and volatilization of herbicides in organo-clay formulations. Applied Clay Science 14(1-3): 105-119.

98. Cypes SH, Saltzman WM, Giannelis EP (2003) Organosilicate-polymer drug delivery systems: Controlled release and enhanced mechanical properties. Journal of Controlled Release 90(2): 163-169.

99. Takahashi T, Yamada Y, Kataoka K, Nagasaki Y (2005) Preparation of a novel PEGclay hybrid as a DDS material: Dispersion stability and sustained release profiles. Journal of Controlled Release 107(3): 408416.

100. Pongjanyakul T, Khunawattanakul W, Puttipipatkhachorn S (2009) Physicochemical characterizations and release studies of nicotinemagnesium aluminum silicate complexes. Applied Clay Science 44(3-4): 242-250.

\section{ISSN: 2574-1241}

\section{DOI: 10.26717 /BJSTR.2020.30.005008}

Adekeye DK. Biomed J Sci \& Tech Res

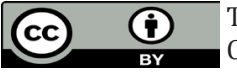

This work is licensed under Creative

Commons Attribution 4.0 License

Submission Link: https://biomedres.us/submit-manuscript.php
101. Dobrozsi DJ (2003) Oral liquid mucoadhesive compositions. US Patent 6: 638, 521 .

102. Hua S, Yang H, Wang W, Wang A (2010) Controlled release of ofloxacin from chitosan montmorillonite hydrogel. Applied Clay Science 50(1): 112-117.

103. Salcedo I, Aguzzi C, Sandri G, Bonferoni MC, Michela Mori, et al. (2012) In vitro biocompatibility and mucoadhesion of montmorillonite chitosan nanocomposite: A new drug delivery. Applied Clay Science 55: 131-137.

104. Alestig K, Trollfors B, Stenqvist K (1979) Acute nonspecific diarrhoea: Studies on the use of charcoal, kaolinpectin and diphenoxylate. The Practitioner 222(1332): 859-862.

105. Ippoliti C (1998) Antidiarrheal agents for the management of treatment-related diarrhea in cancer patients. American Journal of Health-System Pharmacy 55(15): 1573-1580.

106. Bolger R (1995) Industrial minerals in pharmaceuticals. Industrial Minerals 1: 52-63.

107. Abend S, Lagaly G (2000) Solgel transitions of sodium montmorillonite dispersions. Applied Clay Science 16(3-4): 201-227.

108. Lee JH, Choi G, Oh YJ, Park JW, Choy YB, et al. (2012) A nanohybrid system for taste masking of sildenafil. International Journal of Nanomedicine 7: 1635-1649.

109. Oh YJ, Choi G, Choy YB, Park JW, Park JH, et al. (2013) Aripiprazolemontmorillonite: A new organicinorganic nanohybrid material for biomedical applications. Chemistry A European Journal 19(15): 48694875 .

110. Cara S, Carcangiu G, Padalino G, Palomba M, Tamanini M (2000) The bentonites in pelotherapy: Chemical, mineralogical and technological properties of materials from Sardinia deposits (Italy). Applied Clay Science 16(1-2): 117-124.

111. Cara S, Carcangiu G, Padalino G, Palomba M, Tamanini M (2000) The bentonites in pelotherapy: Thermal properties of clay pastes from Sardinia (Italy). Applied Clay Science 16(1): 125-132.

112. Ferrand T, Yvon J (1991) Thermal properties of clay pastes for pelotherapy. Applied Clay Science 6(1): 21-38.

113. De Bernardi M, Pedrinazzi GM (1996) Biological actions of thermal peloids. In: Veniale, F. (Edi.), Atti Convegno Argille Curative, Salice Terme (PV). pp. 17-24.

114. Tateo F, Summa V, Bonelli GC, Bentivenga G (2001) Mineralogy and geochemistry of herbalist's clays for internal use: simulation of the digestive process. Applied Clay Science 20(3): 97-109.

115. Fjar E, Holt RM, Raaen AM, Risnes R, Horsrud P (2008) Petroleum Related Rock Mechanics, Developments in Petroleum Science, $\left(2^{\text {nd }}\right.$ Edn.), Elsevier Press 53: 514.

116. Carretero MI, Pozo M (2010) Clay and non-clay minerals in the pharmaceutical and cosmetic industries part II. Active ingredients. Applied Clay Science 47(3-4): 171-181.

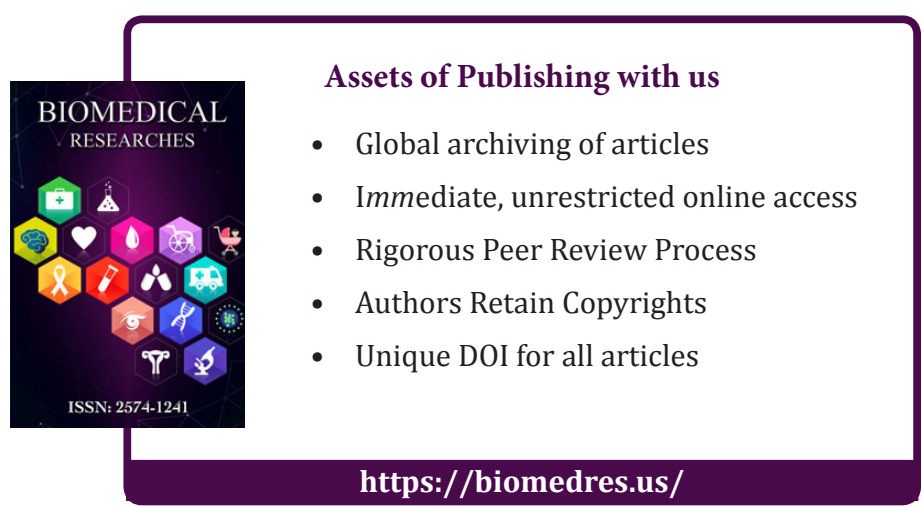

